\title{
MENINGKATKAN STANDAR LAYANAN ACCOUNT OFICER KEPADA NASABAH BPR INTI DANA
}

\author{
${ }^{1}$ Agrasadya, ${ }^{2}$ Syahnego, ${ }^{3}$ Hastu Nugroho Warasto \\ Dosen Fakultas Ekonomi Universitas Pamulang \\ Email : 1. dosen01866@unpam.ac.id
}

\begin{abstract}
ABSTRAK
Adapun sasaran dan tujuan yang ingin dicapai dalam kegiatan Pengabdian Kepada Masyarakat ini adalah memberikan pengetahuan dan keterampilan bagi para account officer agar dapat meningkatkan standar layanan kepada para nasabahnya.

Metode pengabdian dengan membawakan materi tentang bagaimana meningkatkan standar layanan account officer kepada para nasabah BPR Inti dana serta Role Play, Bagaimana cara berkomunikasi yang baik agar nasabah loyal terhadap account officer

Hasil kegiatan pengabdian masyarakat yang kami lakukan bahwa program ini berjalan dengan baik dan terukur, sehingga pesan yang disampaikan dapat tersalurkan kepada para account officer, sehingga kedepan diharapkan dapat menerapkan hal-hal yang telah disampaikan dalam pengabdian masyarakat ini. Dan ini merupakan salah satu cara yang efektif disamping mereka telah mendapatkan training dan seminar yang diadakan oleh perusahaan
\end{abstract}

\section{Kata Kunci : Standar Layanan Account}

\section{PENDAHULUAN}

Bank merupakan sebuah lembaga keuangan umumnya didirikan dengan kewenangan untuk menerima simpanan, memberikan kredit, dan menerbitkan warkat atau giro. Kata bank berasal dari bahasa Italia banca berarti tempat penukaran uang. Sedangkan menurut undang-undang perbankan bank adalah badan usaha yang menghimpun dana dari masyarakat dalam bentuk simpanan dan menyalurkannya kepada masyarakat dalam bentuk kredit dan atau bentuk-bentuk lainnya dalam rangka meningkatkan taraf hidup rakyat banyak.

Industri perbankan telah mengalami perubahan besar dalam beberapa tahun terakhir. Industri ini menjadi lebih kompetitif dengan semakin banyaknya bank yang diakuisisi oleh pihak lain. Saat ini, bank memiliki fleksibilitas pada layanan yang mereka tawarkan, lokasi tempat mereka beroperasi, dan tarif yang mereka bayar untuk simpanan deposan.

Aktivitas perbankan tidak hanya sebatas hanya kepada nasabah tabungan dan transfer saja, melainkan juga aktivitas seperti account dan Lending yang notabene masuk ke dalam marketing suatu perbankan, khususnya pelayanan kepada nasabah yang dilakukan oleh para account officer. 


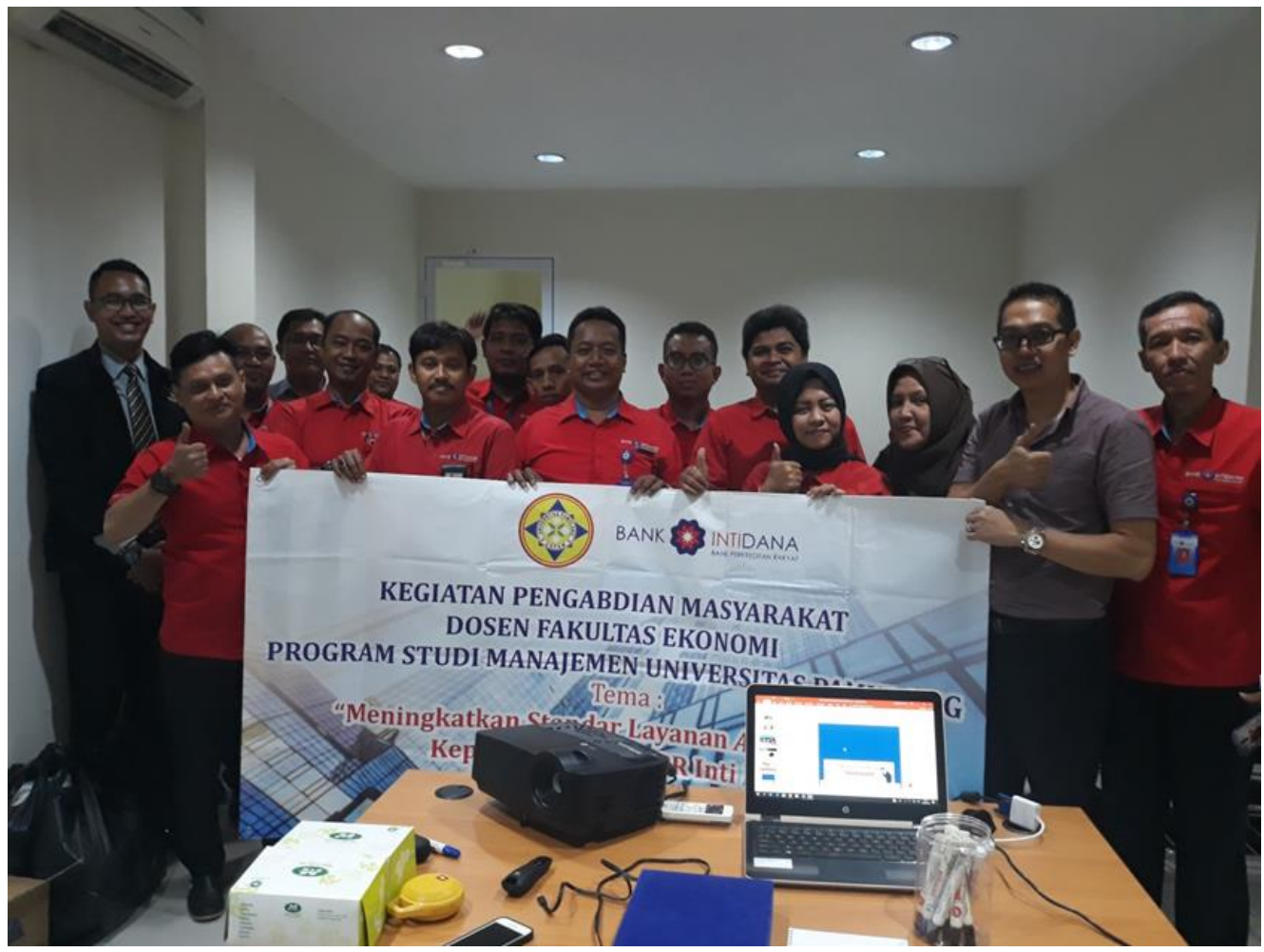

Gambar 1. Dosen Pengabdi dan Peserta

\section{METODE PELAKSANAAN KEGIATAN}

1. Tahapan Persiapan

a. Mengunjungi BPR Inti dana untuk mengajukan proposal kegiatan pengabdian kepada masyarakat

b. Penentuan lokasi dan pemantapan anggota kelompok serta pembagian kerja

c. Penyusunan Bahan materi yang akan dibawakan saat kegiatan berlangsung

2. Tahapan Pelatihan

a. Membawakan materi tentang bagaimana meningkatkan standar layanan account officer kepada para nasabah BPR Inti dana

b. Role Play, Bagaimana cara berkomunikasi yang baik agar nasabah loyal terhadap account officer

\section{HASIL DAN PEMBAHASAN}

Hasil kegiatan dengan berbagai pertimbangan akhirnya pimpinan BPR memutuskan untuk dapat memberikan izin kepada dosen pengabdi program studi manajemen universitas pamulang untuk dapat mengadakan pelatihan dan pengajaran pada BPR Inti dana Jakarta Pusat 


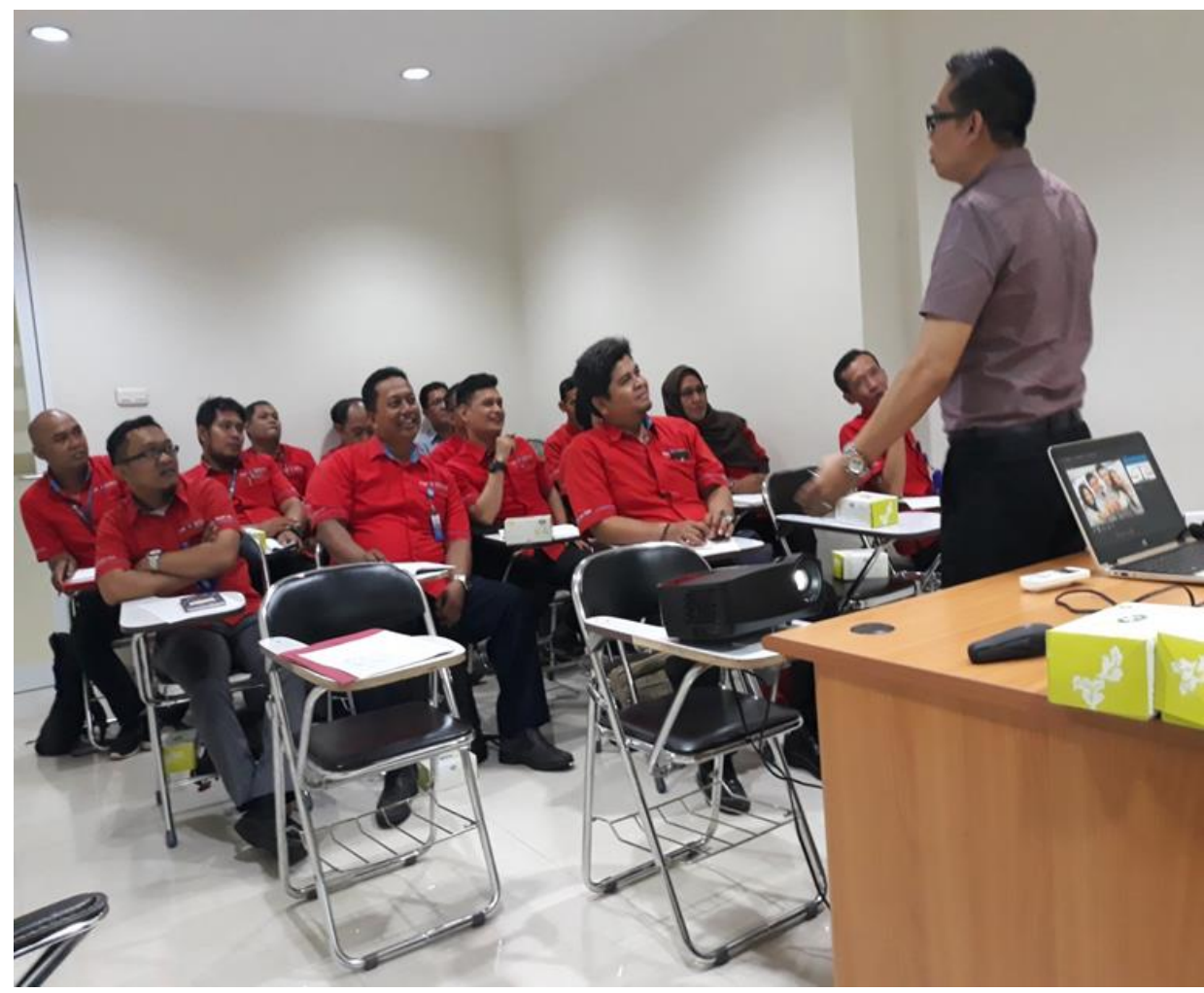

Gambar 2. Pemberian Materi

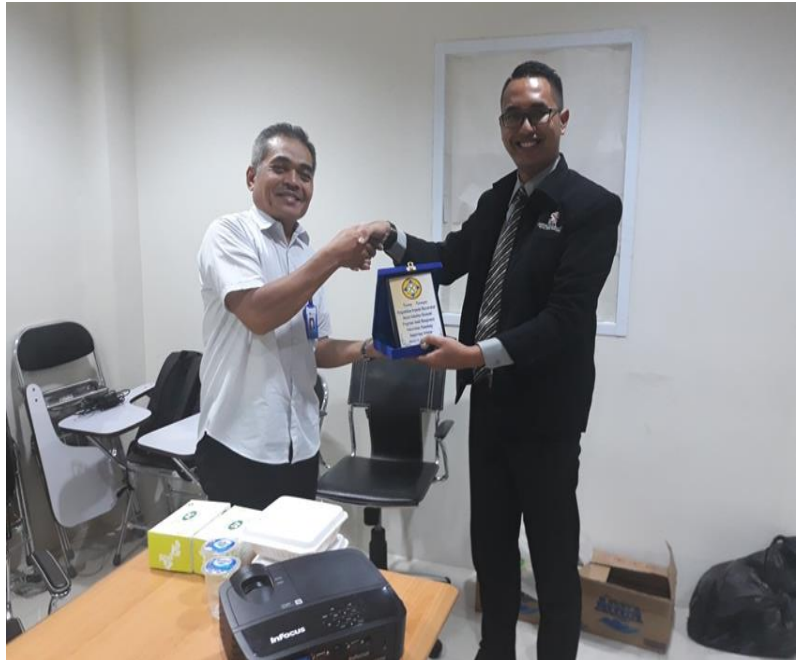

Gambar 3. Pemberian Penghargaan

Pengabdian ini diberi judul "Meningkatkan Standar Layanan Account Officer Kepada Nasabah BPR Inti Dana". Judul ini kami anggap penting, selain karena marketing dianggap sebagai tolak ukur keberhasilan suatu perusahaan, bagaimana pembawaan seorang account officer dalam menghadapi nasabah juga 
merupakan salah satu faktor yang mendukung keberhasilan marketing pada suatu perusahaan, khususnya pada bidang perbankan. Selain itu, pelatihan ini juga dapat membawa dampak yang positif kepada para pegawai perbankan khususnya sales dan marketing agar semakin termotivasi dalam mencapai target yang telah ditentukan oleh perusahaan tesebut

\section{KESIMPULAN DAN SARAN \\ Kesimpulan}

Kegiatan pengabdian masyarakat yang kami lakukan bahwa program ini berjalan dengan baik dan terukur, sehingga pesan yang disampaikan dapat tersalurkan kepada para account officer, sehingga kedepan diharapkan dapat menerapkan hal-hal yang telah disampaikan dalam pengabdian masyarakat ini. Dan ini merupakan salah satu cara yang efektif disamping mereka telah mendapatkan training dan seminar yang diadakan oleh perusahaan.

\section{Saran}

Kami menyarankan kedepan perusahaan lebih meningkatkan lagi kualitas dan kuantitas karyawan, terutama pada bagian marketing dan karyawan yang direkrut haruslah orang-orang yang memang mengenal dunia marketing ini secara gambling, sehingga dapat menyampaikan kepada para nasabah secara lugas, dan dapat mendorong nasabah menjadi loyal terhadap perusahaan, baik itu terhadap produk maupun terhadap account officer perusahaan

\section{DAFTAR PUSTAKA}

Dendawijaya, Lukman. 2001. Manajemen Perbankan. Jakarta : Ghalia Indonesia. Martin, William B. 2004. Quaity Account Officer. Jakarta : Penerbit PPM.

Sunarto, 2006. Account Officer. Yogyakarta : Penerbit Amus.

Undang-Undang Republik Indonesia No. 10 tahun 1998, Tentang Perubahan Undang-Undang No. 7 Tahun 1992 Tentang perbankan.

Yusuf, Jopie. 1995. Analisis Kredit Untuk Account Officer. Jakarta : PT. Gramedia Pustaka Utama. 